\title{
ANOMALI SINYAL STOCHASTIC DAN FIBONACCI TERHADAP PERGERAKAN SAHAM DI BURSA EFEK INDONESIA (BEI) DENGAN METODE ARUS DANA INVESTOR ASING
}

\author{
Yehezkiel Lamora Lumban Tobing \\ yehezkiellamora@gmail.com \\ Ida Syafrida \\ ida.syafrida@akuntansi.pnj.ac.id \\ Ridwan Zulpi Agha \\ readone.agha@gmail.com \\ Program Studi Manajemen Keuangan Politeknik Negeri Jakarta
}

\begin{abstract}
In general, stock analysis is divided into two types; they are fundamental analysis and technical analysis. However, technical analysis has given the false signal in many times when giving buy and sell signal. This study aims to identify the causes of false signals in technical analysis using stochastic and Fibonacci indicators, find solutions to anticipate the occurrence of false signals on stock movements using the method of foreign investor funds flow, and formulates an investment strategy to make purchases and sales in a portfolio investment. The objects of the study are PT Astra International Tbk, PT Bank Tabungan Negara Tbk and PT Telekomunikasi Indonesia. The research combines technical analysis and foreign flow analysis as a data analysis technique. Technical analysis was using stochastic and Fibonacci indicator, which is then explained descriptively by entering the foreign flow analysis. The results showed that the flow of foreign investors' funds led to fluctuations in stock prices and triggering the occurrence of false signals on the stochastic and Fibonacci indicators. The capital inflow led to a rise in stock prices while capital outflows caused a decline in stock prices.
\end{abstract}

Keywords: technical analysis, foreign flow, false signal

\section{ABSTRAK}

Pada umumnya analisis saham terbagi dua yaitu analisis fundamental dan analisis teknikal. Namun, analisis teknikal sering kali salah dalam memberikan sinyal jual dan beli. Penelitian ini bertujuan untuk mengidentifikasi penyebab terjadinya false signal pada analisis teknikal yang menggunakan indikator stochastic dan fibonacci, menemukan solusi untuk mengantisipasi terjadinya false signal pada pergerakan saham dengan menggunakan metode arus dana investor asing, dan merumuskan strategi investasi untuk melakukan pembelian dan penjualan dalam melakukan perubahan portofolio investasi. Penelitian mengambil tiga objek penelitian yaitu saham PT Astra International Tbk, PT Bank Tabungan Negara Tbk, dan PT Telekomunikasi Indonesia Tbk. Penelitian mengkombinasikan analisis teknikal dan analisis arus dana investor asing sebagai teknik analisis data. Analisis teknikal menggunakan indikator stochastic dan fibonacci yang kemudian dijelaskan secara deskriptif dengan memasukkan analisis arus dana investor asing. Hasil penelitian menunjukkan bahwa arus dana investor asing menyebabkan terjadinya fluktuasi harga saham sehingga memicu terjadinya false signal pada indikator stochastic dan fibonacci. Arus masuk dana asing menyebabkan kenaikan harga saham sedangkan arus keluar dana asing menyebabkan penurunan harga saham.

Kata kunci: analisis teknikal, arus dana investor asing, kesalahan sinyal .

\section{PENDAHULUAN \\ Latar Belakang}

Pertumbuhan investasi di suatu negara ditentukan oleh pertumbuhan ekonomi di negara tersebut. Pasar modal merupakan cerminan dari keadaan ekonomi suatu negara. Sebagai negara emerging market yang masuk ke dalam 20 negara dengan perekonomian terbesar (G-20), pasar modal Indonesia menjadi salah satu pasar modal terbaik di Asia. Indonesia dianggap layak sebagai negara tujuan investasi setelah lembaga pemeringkat seperti Fitch Ratings, Standard \& Poor's, dan Moody's menaikan peringkat Indonesia. Fitch 
Ratings menaikan peringkat menjadi BBB dengan outlook stabil. Saat ini Moody's menyematkan peringkat Baa3 (investment grade) dengan outlook positif sementara Standard \& Poors memberikan peringkat BBB- dengan outlook stabil. Dengan peringkat Indonesia yang dinilai layak sebagai negara tujuan investasi, tentu akan meningkatkan kepercayaan investor di seluruh dunia.

Kustodian Sentral Efek Indonesia (KSEI) mencatat per 29 Desember 2017 aset yang disimpan di KSEI mencapai Rp 4.423,07 Triliun. Jumlah investor pasar modal di Indonesia mencapai 1.122.668 per Desember 2017. Pertumbuhan jumlah investor ini diikuti dengan pertumbuhan jumlah investor domestik. Pada tahun 2012 jumlah investor domestik sebesar $45,58 \%$ dari total investor sementara per Desember tahun 2017 jumlah investor domestik mencapai $54,50 \%$ dari total jumlah investor di pasar modal. Bukan hanya dari pertumbuhan aset dan jumlah investor, Indeks Harga Saham Gabungan (IHSG) juga terbukti meningkat dari tahun ke tahun.

Tingginya imbal hasil (return) yang dihasilkan oleh IHSG dalam jangka pendek dan jangka panjang membuat sebagian besar investor lebih memilih saham dibanding instrumen pasar modal lain sebagai sarana investasi dalam portofolionya. Gambar 1 memperlihatkan jumlah dan jenis efek yang disimpan di Kustodian Sentral Efek Indonesia (KSEI).

\section{Jumlah dan Jenis Efek disimpan di KSEI}

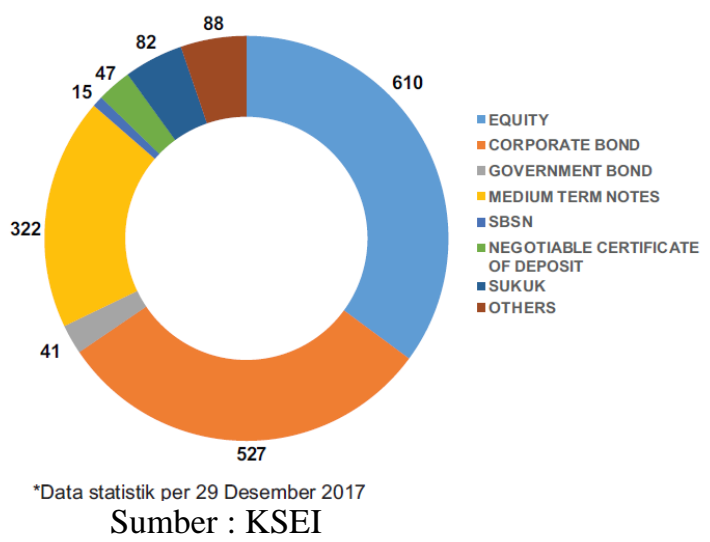

Pada Gambar 1.2 terlihat bahwa saham menjadi instrumen paling tinggi yang dimiliki investor, diikuti obligasi perusahaan ditempat kedua dan Medium Term Notes (MTN) di peringkat ketiga. Selain karena memiliki return yang tinggi, saham juga membagikan hasil keuntungan perusahaan dalam bentuk deviden. Saham juga termasuk instrumen investasi yang terbilang liquid dibandingkan dengan instrumen lainnya. Alasan investor lebih memilih saham sebagai sarana investasi terletak pada kebebasan waktu berinvestasi dan likuiditasnya. Investasi pada saham memiliki potensi return yang tinggi. Namun demikian, investasi saham tidak pernah terlepas dari risiko. Semakin tinggi return sebuah investasi semakin besar juga risiko yang dihadapi investor.

Risiko memang tidak bisa dihindari tetapi bisa diminimalisir dengan melakukan analisis. Menurut May (2011), analisis saham dibagi menjadi dua metode yaitu analisis fundamental dan analisis teknikal. Analisis fundamental berfokus pada laporan keuangan perusahaan sedangkan analisis teknikal lebih memusatkan perhatian pada pergerakan harga saham yang dilihat dari grafik dan indikator. Penggunaan analisis ini dibedakan dari jangka waktu berinvestasi. Jika dilihat dari penelitian terdahulu, terdapat hasil return yang tidak optimal dalam penggunaan analisis teknikal. Luciana (2008) menyatakan aliran masuk investor asing (foreign inflow) berpengaruh positif terhadap return saham. Prabhata (2012) menyatakan bahwa analisis teknikal dapat memberikan capital gain bagi investor tetapi tidak bisa menghasilkan abnormal return. Pramono (2013) menyimpulkan bahwa metode buy and hold lebih optimal dalam memberi keuntungan daripada menggunakan analisis teknikal dengan indikator MACD, RSI dan stochastic.

Saat ini, analisis teknikal sangat populer dikalangan pelaku pasar dan analis. Banyak investor membutuhkan analis untuk memberikan rekomendasi terkait saham yang ingin ditransaksikan. Umumnya analis akan memberikan pandangannya terhadap saham dengan menggunakan analisis teknikal. Pemilihan indikator oleh pelaku pasar ditentukan oleh pemahaman dan kenyamanan pelaku pasar dalam menggunakan indikator. Namun demikian, penggunaan analisis teknikal beberapa kali memberi false signal atau kesalahan dalam membaca pergerakan harga saham.

\section{Tujuan}

Merujuk pada permasalahan dan pertanyaan penelitian, penelitian ini bertujuan untuk: 
1. Mengidentifikasi penyebab terjadinya false signal pada analisis teknikal dengan indikator stochastic dan rasio fibonacci pada saham ASII, BBTN, dan TLKM.

2. Menemukan solusi untuk mengantisipasi terjadinya false signal pada saham ASII, BBTN, dan TLKM

3. Merumuskan strategi investasi untuk melakukan pembelian dan penjualan dalam melakukan perubahan portofolio investasi.

\section{Permasalahan}

Berdasarkan permasalahan pada latar belakang, maka rumusan masalah yang akan diteliti pada penelitian ini adalah:

1. Mengapa hasil analisis teknikal dengan indikator stochastic dan rasio fibonacci bisa menghasilkan false signal atau gagal membaca arah pergerakan saham ASII, BBTN, dan TLKM ?

2. Bagaimana solusi untuk mengantisipasi terjadinya false signal pada saham ASII, BBTN, dan TLKM ?

3. Bagaimana strategi investasi yang tepat untuk melakukan pembelian dan penjualan dalam melakukan perubahan portofolio investasi ?

\section{TINJAUAN PUSTAKA Analisis Teknikal}

Pistole (2009) mendefinisikan analisis teknikal sebagai pendekatan untuk peramalan keuangan dan masa depan harga saham dengan meneliti pola-pola perubahan harga dan perubahan volume perdagangan. Menurut Singgih (2015), analisis teknikal merupakan suatu teknik yang digunakan untuk menganalisis terjadinya fluktuasi harga saham dengan cara melihat keseluruhan saham yang ada pada pasar modal. Tampak setuju dengan kedua definisi diatas, Tandelilin (2010) menyatakan bahwa analisis teknikal adalah teknik untuk memprediksi arah pergerakan saham serta indikator pasar saham lainnya berdasarkan pada data pasar historis seperti informasi harga dan volume.

Analisis teknikal tidak hanya bisa digunakan dalam instrumen pasar modal tetapi juga bisa digunakan untuk analisis transaksi valuta asing dan komoditas. Analisis teknikal menggunakan grafik-grafik yang terbentuk sebagai dasar utama untuk membaca pergerakan harga dalam rentang waktu pendek, menengah, dan panjang.

\section{False Signal}

Menurut Sulistiyono (2011), false signal adalah sinyal palsu yang diberikan oleh formasi candlestick,indikator, atau tidak tercapainya target profit yang berbasis level fibonacci. False signal terjadi karena adanya perbedaan pergerakan harga dengan sinyal yang diberikan indikator. Banyak faktor yang bisa menyebabkan terjadinya false signal. False signal bisa terjadi karena setiap investor memiliki kesimpulan yang berbeda-beda dari hasil analisis teknikal mereka. Titik beli dan titik jual masing-masing investor bisa berbedabeda tergantung sudut pandang analisis setiap investor. Alasan lainnya adalah karena adanya intervensi dari beberapa pihak tertentu seperti investor asing, pemain besar atau lembaga yang turut mengambil bagian dalam pergerakan harga saham.

\section{Analisis Arus Dana Investor Asing}

Analisis arus dana asing (foreign flow) adalah analisis yang mempelajari tentang keluar masuknya dana investor asing didalam suatu pasar atau suatu saham yang dipercaya dapat menggerakkan harga saham (Argha, 2012). Menurut Teori Dow (May, 2011) sebagai cikal bakal analisis teknikal, pergerakan harga saham terbagi dalam tiga fase yaitu fase akumulasi, fase partisipasi publik dan fase distribusi. Fase akumulasi dilakukan ketika investor asing mulai melakukan pembelian, fase partisipasi publik terjadi ketika investor publik mulai melirik saham yang mulai naik dan biasanya disertai dengan berita-berita positif sedangkan fase distribusi dilakukan ketika investor asing mulai melakukan penjualan saham ketika terjadi euforia dalam fase partisipasi publik. Dalam praktiknya, investor asing jarang sekali melakukan manuver pembelian atau penjualan dalam satu hari. Volume dana yang digunakan investor asing biasanya sangat besar dan jauh kemungkinan jika investor asing ingin melakukan jual beli dalam waktu sehari. Oleh karena volume dana yang digunakan sangat besar, investor asing melakukan pembelian atau penjualan secara bertahap dalam waktu bermingu-minggu atau berbulan (Utomo, 2011).

Investor asing memiliki dana yang begitu besar karena sebagian besar dari investor asing ini adalah investor institusi. Dana yang digunakan investor institusi tersebut bisa dana perusahaan itu sendiri 
ataupun himpunan dana investor yang dikelola oleh manajer investasi, maka tidak heran jika dana investor begitu besar dan mampu mempengaruhi pergerakan harga saham. Dalam kasus Indonesia, penelitian yang dilakukan oleh Frensidy (2009) mendapatkan bahwa aliran bersih dana asing mempengaruhi IHSG secara positif dan signifikan. Menurut Hartanto (2017), analisis teknikal bisa dibantah oleh investor institusi yang akan membeli dan menjual saham hanya pada harga-harga tertentu yang mereka suka. Investor institusi tidak akan terpaku oleh batasan support dan resistance. Jika investor institusi memiliki dana yang besar dan mampu menggerakan harga, maka mereka tidak selalu membeli dan menjual berdasarkan support dan resistance. Kemampuan investor asing dalam mempengaruhi pergerakan harga saham inilah yang diduga sebagai penyebab terjadinya false signal pada indikator stochastic dan rasio fibbonacci.

\section{Fase Akumulasi}

Fase Akumulasi adalah fase investor asing atau investor institusi melakukan pembelian saham secara besar-besaran di harga rendah. Tujuan dilakukannya akumulasi adalah untuk menghabiskan jumlah barang di pasar supaya jumlahnya sedikit. Semakin sedikit jumlah barang, semakin tinggi permintaan, semakin mahal harganya (Hartanto, 2017). Fase akumulasi biasa dilakukan ketika grafik saham berada pada tren stagnan atau downtrend karena para investor institusi bisa mendapatkan saham dengan harga yang relatif murah. Dalam kondisi ini, investor kecil atau biasa disebut investor ritel hampir tidak ada yang berani melakukan pembelian karena pasar diiringi dengan rasa takut dan panic selling (Argha, 2012). Perasaan takut dari para pelaku pasar ini yang semakin mempermudah investor institusi dalam melakukan akumulasi karena saat itu investor ritel bersama-sama melakukan penjualan. Investor ritel terbukti melakukan penjualan secara bersamaan tercermin dalam data transaksi dibawah ini disesuaikan dengan periode akumulasi diatas.

\section{Fase Distribusi}

Fase Distribusi adalah fase dimana saham disebarkan untuk dimiliki banyak orang. Menurut Filbert (2014), ciri fase distribusi adalah jumlah penjual lebih sedikit tetapi memiliki nilai yang besar sedangkan pihak pembeli lebih banyak jumlahnya tetapi nilainya relatif lebih menyebar. Penurunan harga saham adalah efek dari dilakukannya distribusi karena penjualan investor asing dilakukan dengan volume yang besar. Fase ini terjadi ketika saham berada pada euforia saat semua investor optimis dan berbagai berita baik mengenai saham ini telah muncul dan beredar (Dermawan, 2017). Dalam fase ini, investor ritel secara bersama-sama melakukan pembelian saham karena sudah euforia dengan kenaikan harga sebelumnya dan berharap bahwa harga saham akan kembali naik ketika mereka melakukan pembelian saham. Perasaan euforia dan harapan akan kenaikan harga saham inilah yang mempermudah investor institusi dalam melakukan penjualan saham dengan jumlah besar karena investor ritel sudah bersedia untuk membeli saham tersebut di harga tinggi.

\section{METODE PENELITIAN Jenis Penelitian}

Penelitian ini menggunakan jenis penelitian kualitatif. Peneliti mengambil tiga objek penelitian yang dianggap mampu mewakili analisis keseluruhan saham yang tercatat di Bursa Efek Indonesia. Data yang diambil dalam penelitian ini merupakan data sekunder. Data tersebut akan diobservasi dan didokumentasi sebagai bahan dalam melakukan analisis. Penelitian menggunakan analisis teknikal dan analisis arus dana asing sebagai teknik analisis data dengan desain deskriptif yang bertujuan untuk menganalisis dan mendeskripsikan penyebab terjadinya pergerakan harga saham secara langsung.

\section{Objek Penelitian}

Pemilihan sampel penelitian ini menggunakan teknik purposive sampling yang diambil dari perusahaan tercatat di Bursa Efek Indonesia (BEI) dengan ketentuan sebagai berikut :

1. Perusahaan yang listing di Bursa Efek Indonesia (BEI) sampai dengan tahun 2017

2. Masuk dalam kategori 50 perusahaan dengan kapitalisasi terbesar di Bursa Efek Indonesia

3. Komposisi kepemilikan efek investor asing di lebih besar dari investor lokal

4. Seringnya terjadi false signal pada harga saham periode 2017. 


\section{Variabel Penelitian}

Data diperoleh dari hasil pengamatan pergerakan harga saham dan arus dana investor asing pada perusahaan yang tercatat di Bursa Efek Indonesia yaitu PT Astra International, Telekomunkasi Indonesia (persero), dan Bank Tabungan Negara (persero). Pengamatan dilakukan dengan menggunakan perangkat lunak (software) ChartNexus versi 5.0. Terdapat lima variabel yang digunakan dalam penelitian ini yaitu aliran dana asing, indikator stochastic, fibonacci, pergerakan harga saham dan keputusan investasi.

\section{TEKNIK ANALISIS DATA Analisis Teknikal}

Analisis teknikal yang dilakukan dalam penelitian ini menggunakan dua indikator yaitu indikator stochastic dan rasio fibonacci. Pada penelitian ini, analisis teknikal sekaligus digunakan untuk menemukan adanya false signal. Berikut cara melakukan analisis teknikal dengan kedua indikator tersebut:

\section{Indikator Stochastic}

Cara menggunakan indikator stochastic adalah berfokus pada oscillator yang terbentang dari kisaran 0\%-100\% dan memperhatikan potongan dua garis yaitu garis $\% \mathrm{~K}$ dan $\% \mathrm{D}$. Gambar 2 menampilkan contoh bentuk indikator stochastic. Apabila garis $\% \mathrm{~K}$ memotong garis \% D keatas dalam rentang oscillator $0 \%-20 \%$, hal ini merupakan sinyal beli bagi investor.

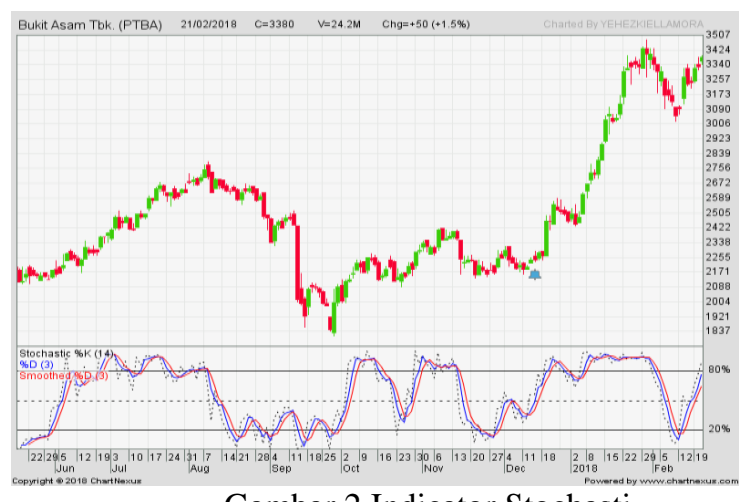

Gambar 2 Indicator Stochasti

Sumber : ChartNexus

Sebaliknya, jika garis \%D memotong garis $\% \mathrm{~K}$ kebawah dalam rentang oscillator $80 \%-100 \%$, berarti merupakan sinyal jual bagi investor. Jika terjadi perpotongan garis \%D dan $\% \mathrm{~K}$ dalam rentang oscillator $21 \%-79 \%$, artinya stochastic memberikan sinyal netral atau hold bagi investor.

\section{Rasio Fibonacci}

Dalam indikator fibbonacci terdapat tujuh level utama yaitu $0 \%, 23,6 \%, 38,2 \%$, $50 \%, 61,8 \%, 78,6 \%$, dan $100 \%$. Gambar 3 berikut menunjukkan level rasio fibonacci.

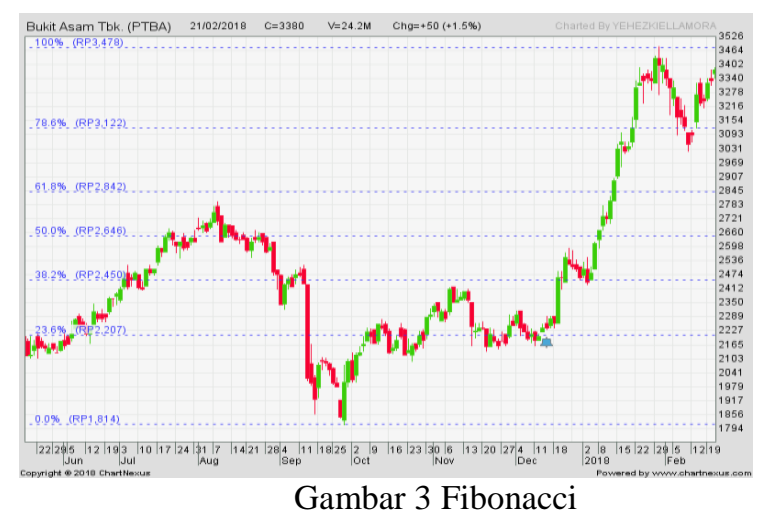

Sumber : ChartNexus

Level fibonacci ditarik dari titik terendah harga saham ke titik tertinggi harga saham. Setiap level merupakan sinyal support dan resistance yang kuat pada sebuah harga. Apabila suatu harga turun mencapai level fibonacci, hal terebut dianggap sebagai sinyal beli karena menyentuh support. Begitu juga jika suatu harga naik mencapai level fibonacci maka dianggap sebagai sinyal jual karena menyentuh resistance.

\section{Analisis Arus Dana Investor asing}

Analisis arus dana asing yang dilakukan pada penelitian ini menggunakan nilai bersih (nett) transaksi jual dan beli investor asing. Analisis arus dana asing berguna untuk mengetahui adanya aktivitas akumulasi dan distribusi yang dilakukan oleh investor asing ataupun investor institusi yang memiliki dana besar. Cara melakukan analisis arus dana asing ini adalah dengan menggunakan perangkat lunak (software) Ipot versi 5.5.2.1 dari Indo Premier Securities. Setelah itu membuka kolom nett broker pada aplikasi tersebut. Aplikasi akan menampilkan data perdagangan dari setiap sekuritas yang bertansaksi pada saham yang diteliti. Dalam data perdagangan tersebut akan ditampilkan berupa kode broker, rata-rata harga pembelian dan penjualan serta jumlah lembar saham yang sudah diperjual belikan.

Investor bebas memilih saham yang akan diteliti datanya dan periode data tersebut juga ditentukan oleh investor dengan 
memasukkan tanggal awal dan akhir periode data transaksi saham yang akan diteliti. Fase distribusi terjadi jika jumlah penjual lebih sedikit tetapi memiliki nilai yang besar sedangkan pihak pembeli lebih banyak jumlahnya tetapi nilainya relatif lebih menyebar. Fase akumulasi terjadi jika jumlah pembeli lebih sedikit tetapi memiliki nilai yang besar sedangkan pihak penjual lebih banyak tetapi nilainya relatif lebih menyebar (Filbert, 2014).

\section{HASIL DAN PEMBAHASAN}

Berdasarkan kriteria sampel yang telah dijelaskan pada metodologi penelitian, maka hasil pemilihan sampel sebagai berikut.

Tabel 1 Penentuan Sample

\begin{tabular}{|l|c|}
\hline \multicolumn{1}{|c|}{ Keterangan } & Jumlah \\
\hline Perusahaan listing sampai dengan 2017 & 576 \\
(-) Non kategori 50 kapitalisasi terbesar & $(526)$ \\
Perusahaan 50 kapitalisasi terbesar & 50 \\
(-) Perusahaan dengan kepemilikan asing < lokal & $(25)$ \\
Perusahaan dengan kepemilikan asing > lokal & 25 \\
(-) Perusahaan dengan jumlah false signal $\leq 4$ & 22 \\
Perusahaan dengan jumlah false signal $\geq 4$ & 3 \\
\hline
\end{tabular}

Dari Tabel 1 diperoleh sampel penelitian sebanyak tiga perusahaan yang disajikan pada Tabel 2 sebagai berikut.

Tabel 2

\begin{tabular}{c|c|c|c|c|}
\hline Nama Saham & $\begin{array}{c}\text { Jumlah Saham } \\
\text { Publik }\end{array}$ & $\begin{array}{c}\text { Persentase } \\
\text { Lokal }\end{array}$ & Persentase Asing & $\begin{array}{c}\text { Jumlah False } \\
\text { Signal }\end{array}$ \\
\hline ASII & $45,09 \%$ & $11,83 \%$ & $33,26 \%$ & 10 \\
\hline TLKM & $48,75 \%$ & $11.38 \%$ & $37,36 \%$ & 6 \\
\hline BBTN & $40 \%$ & $10,05 \%$ & $29,94 \%$ & 4 \\
\hline
\end{tabular}

Tabel 3; Sample

Sumber : KSEI, diolah

Pada Tabel 2 ditunjukkan bahwa sebagian besar komposisi kepemilikan saham PT Astra International Tbk, PT Telekomunikasi Indonesia Tbk, dan PT Bank Tabungan Negara Tbk dimiliki oleh investor asing.

\section{Kondisi Pasar}

Sejak awal Januari 2018, Indeks Harga Saham Gabungan (IHSG) terus meningkat mencapai level tertingginya sepanjang masa. Hal ini dibuktikan saat awal Januari 2018 IHSG berada pada level Rp 6.366 dan pada awal Februari 2018 IHSG berada pada level Rp 6.605. Sebuah pencapaian yang baik dari IHSG ketika mampu melewati level psikologis Rp 6.000. Meningkatnya IHSG membuat banyak pelaku pasar seperti investor dan analis semakin percaya diri bahwa tahun
2018 IHSG akan terus naik hingga mencapai level Rp 7.000. Menurut Bahana Sekuritas, mereka optimis Indeks Harga Saham Gabungan (IHSG) di 2018 bisa mencapai level Rp 7.000 (www.kontan.co.id/news/ramalanbahana-sekuritas-ihsg-tembus-7000-di-2018, 9 Mei 2018, 10.00 WIB). Bahkan dilansir CNN Indonesia (2017), Otoritas Jasa Keuangan (OJK) memperkirakan IHSG akan tumbuh 25\% pada 2018 ke level Rp 7.943.

Ironinya ditengah kenaikan IHSG yang fenomenal, investor asing justru tercatat melakukan penjualan bersih secara besarbesaran. Dilihat dari RTI Business, sejak pertengahan Februari 2018 sampai 30 April 2018 investor asing sudah melakukan penjualan bersih di seluruh pasar sebesar 37,52 Triliun Rupiah. Begitu juga dengan level IHSG yang terus menurun hingga akhir April 2018 sudah berada di bawah level Rp 6.000 tepatnya pada level Rp 5.994. Jika diperkecil dengan melihat fokus objek penelitian yaitu PT Astra International Tbk, PT Telekomunikasi Indonesia Tbk, dan PT Bank Tabungan Negara Tbk, penurunan harga pasar juga dialami oleh ketiga saham perusahaan tersebut. Tabel 3 akan memberikan gambaran yang lebih jelas mengenai pergerakan harga saham dan transkasi bersih investor asing sejak 1 Februari 2018 sampai 30 April 2018.

Tabel 3 Transaksi Bersih Investor Asing

\begin{tabular}{|c|c|c|c|c|}
\hline Saham & Harga 1 Februari 2018 & Harga 30 April 2018 & Imbal hasil & Investor Asing \\
\hline ASII & 8.525 & 7.150 & $-19 \%$ & Rp -3,695 Triliun \\
\hline BBTN & 3.660 & 3.110 & $-15 \%$ & Rp -457,1 Milyar \\
\hline TLKM & 4.030 & 3.830 & $-4.9 \%$ & Rp -1,871 Triliun \\
\hline
\end{tabular}

Sumber : Yahoo Finance, Indopremier

Securities, diolah

Dari ketiga saham tersebut, tidak ada saham yang berhasil mencatatkan imbal hasil (return) positif dan tidak ada satupun saham yang tidak dijual oleh investor asing.

\section{Kombinasi Analisis Teknikal dan Arus Dana Investor Asing PT Astra International Tbk}

Analisis yang dilakukan pada saham PT Astra International dilakukan pada rentang periode Januari 2017 sampai Februari 2018. Dalam melakukan analisis teknikal menggunakan indikator stochastic dan rasio fibonacci, ditemukan setidaknya ada 10 kali false signal yang terjadi pada saham ASII dalam rentang tersebut. 
Tabel 4 Signal Indokator Stochastic

\begin{tabular}{c|c|c|c|c|c}
\hline No. & Tanggal & Sinyal Stochastic & Realisasi & Sinyal Fibonacci & Realisasi \\
\hline 1 & $17 / 02 / 2017$ & Deadcross (turun) & Naik & Breakdown (turun) & Naik \\
\hline 2 & $16 / 03 / 2017$ & Deadcross (turun) & Naik & Breakdown (turun) & Naik \\
\hline 3 & $06 / 04 / 2017$ & Deadcross (turun) & Turun & Breakout (naik) & Turun \\
\hline 4 & $20 / 04 / 2017$ & Goldencross (naik) & Naik & Breakdown (turun) & Naik \\
\hline 5 & $25 / 04 / 2017$ & Deadcross (turun) & Turun & Breakout (naik) & Turun \\
\hline 6 & $14 / 06 / 2017$ & Deadcross (turun) & Turun & Breakout (naik) & Turun \\
\hline 7 & $13 / 07 / 2017$ & Goldencross (naik) & Turun & Support (naik) & Turun \\
\hline 8 & $21 / 07 / 2017$ & Goldencross (naik) & Turun & Breakdown (turun) & Turun \\
\hline 9 & $04 / 10 / 2017$ & Deadcross (turun) & Naik & Resistance (turun) & Naik \\
\hline 10 & $30 / 11 / 2017$ & Deadcross (turun) & Naik & Breakdown (turun) & Naik \\
\hline
\end{tabular}

Sumber : ChartNexus, diolah

Tabel 4 menjelaskan bahwa sinyal yang diberikan oleh indikator stochastic dan rasio fibonacci sering kali salah membaca pergerakan harga saham ASII. Indikator stochastic benar dalam membaca pergerakan harga pada tanggal 4 April 2017, 17 April 2017, 21 April 2017 dan 14 Juni 2017 tetapi rasio fibonacci seluruhnya salah pada tanggal tersebut. Sebaliknya, rasio fibonacci pada tanggal 21 Juli 2017 berhasil membaca pergerakan harga saham tetapi indikator stochastic salah membaca pergerakan harganya. Diluar tanggal yang telah disebutkan, kedua indikator sepenuhnya salah membaca pergerakan harga saham ASII

\section{PT Bank Tabungan Negara Tbk}

Pergerakan saham PT Bank Tabungan Negara Tbk tidak luput dari adanya kesalahan analisis teknikal (false signal) dalam membaca arah pergerakan saham.

Tabel 5 Penggunaan Indikator Stochastic

\begin{tabular}{|c|c|c|c|c|c|}
\hline No. & Tanggal & Sinyal Stochastic & Realisasi & Sinyal Fibonacci & Realisasi \\
\hline 1 & $12 / 07 / 2017$ & Goldencross (naik) & Naik & Breakdown (turun) & Naik \\
\hline 2 & $31 / 07 / 2017$ & Deadcross (turun) & Naik & Breakout (naik) & Naik \\
\hline 3 & $23 / 08 / 2017$ & Deadcross (turun) & Naik & Breakout (naik) & Naik \\
\hline 4 & $04 / 10 / 2017$ & Goldeencross (naik) & Naik & Breakdown (turun) & Naik \\
\hline 5 & $13 / 10 / 2017$ & Goldeencross (naik) & Turun & Breakout (naik) & Turun \\
\hline 6 & $28 / 11 / 2017$ & Deadcross (turun) & Naik & Breakout (naik) & Naik \\
\hline
\end{tabular}

Sumber : ChartNexus,diolah

Tabel 5 menunjukkan penggunaan indikator stochastic dan rasio fibonacci disertai adanya false signal yang terjadi pada saham PT Bank Tabungan Negara Tbk. Pada saham BBTN terdapat enam kali kesalahan sinyal pergerakan saham yang diberikan indikator stochastic dan rasio fibonacci. Kesalahan- kesalahan tersebut dirangkum pada Tabel 5.Sinyal yang diberikan indikator stochastic dan rasio fibonacci terkadang mampu menunjukkan sinyal yang benar terhadap arah pergerakan saham. Namun demikian, kedua indikator tersebut tidak pernah secara bersamaan menyatakan sinyal yang benar.

\section{PT Telekomunikasi Indonesia Tbk}

Analisis teknikal pada saham PT Telekomunikasi Indonesia Tbk menemukan setidaknya ada empat kali false signal yang terjadi.

Tabel 6

\begin{tabular}{|c|c|c|c|c|c|}
\hline No. & Tanggal & Sinyal Stochastic & Realisasi & Sinyal Fibonacci & Realisasi \\
\hline 1 & $09 / 03 / 2017$ & Deadcross (turun) & Naik & Continue (Naik) & Naik \\
\hline 2 & $20 / 04 / 2017$ & Deadcross (turun) & Naik & Breakdown (turun) & Naik \\
\hline 3 & $11 / 10 / 2017$ & Goldencross (naik) & Turun & Breakdown (turun) & Turun \\
\hline 4 & $23 / 10 / 2017$ & Goldencross (naik) & Turun & Support (naik) & Turun \\
\hline
\end{tabular}

Sumber : ChartNexus, diolah

Dari empat false signal yang terjadi seluruh indikator stochastic menujukkan kesalahan sedangkan rasio fibonacci menujukkan dua kali terjadi kesalahan.

\section{Solusi dan Strategi Investasi}

Tidak bisa dihindari bahwa kedua indikator tidak selalu memberikan pentunjuk sinyal yang benar untuk membaca arah pergerakan harga saham. Penelitian menghasilkan fakta bahwa pergerakan IHSG dan saham individual dipengaruhi oleh aktivitas transaksi yang dilakukan oleh investor asing. Penurunan yang terjadi pada IHSG sejak bulan Maret 2018 merupakan respon atas penjualan investor asing sejak bulan Februari. Begitu juga dengan naik turunnya saham ASII, BBTN, dan TLKM dipengaruhi oleh aksi beli dan jual investor asing. Jadi, solusi untuk mengurangi terjadinya kesalahan dalam membaca arah pergerakan saham adalah dengan memberikan perhatian kepada transaksi yang dilakukan oleh investor asing dan mengikuti pola aliran dana investor asing.

Untuk mengikuti pola aliran dana investor asing maka strategi yang dibutuhkan adalah strategi pasif dalam menunggu konfirmasi aliran dana investor asing dan secara aktif melakukan pembelian atau penjualan dalam merespon keluar masuknya aliran dana investor asing. 
Sebagai contoh, pada tanggal 31 Juli 2017 indikator stochastic menunjukkan sinyal deadcross pada saham BBTN. Langkah pertama adalah melihat data transaksi investor asing pada tanggal tersebut. Sesuai dengan Gambar 4, investor asing tercatat melakukan pembelian sebesar 639,5 juta Rupiah walaupun saat itu indikator stochastic memberi sinyal deadcross. Masuknya arus dana asing ini menjadi sinyal beli bagi investor pada kisaran harga Rp 2.580.

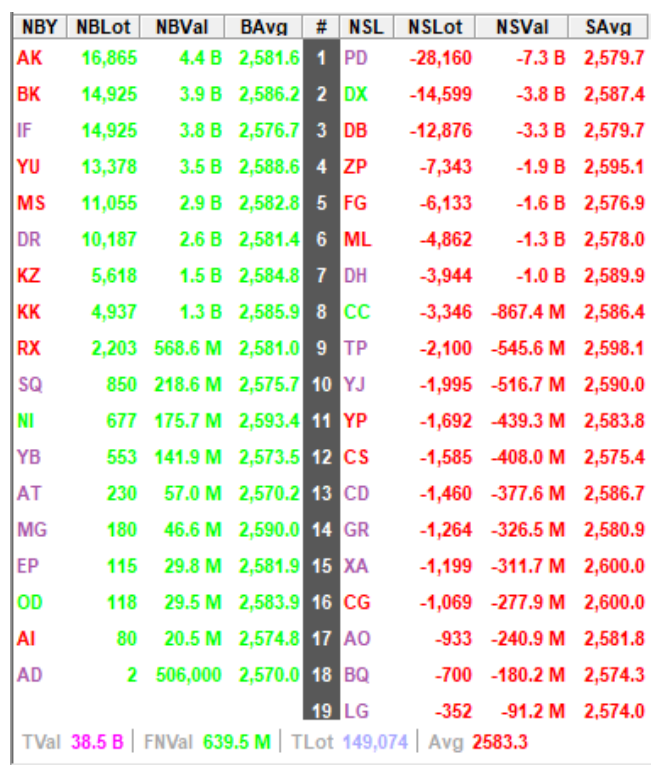

Gambar 4 transaksi investor asing pada tanggal tersebut

Sumber : Indopremier Securities

Langkah kedua setelah membeli saham BBTN adalah melakukan kontrol terhadap aliran dana asing dengan memeriksa data transaksi investor pada sinyal deadcross berikutnya. Sinyal deadcross kembali muncul pada tangggal 22 Agustus 2017. Berikut data transaksi investor pada 22 Agustus 2017. \begin{tabular}{|l|c|c|c|c|c|c|c|c|}
\hline NBY & NBLot & NBVal & BAvg & \# & NSL & NSLot & NSVal & SAvg \\
\hline RX & 40,167 & 11.6 & 2.882 .0 & 1 & PD & $-55,340$ & $-15.9 \mathrm{~B}$ & $2,875,9$ \\
& & & & & & &
\end{tabular}

\begin{tabular}{|lrrrrrrrr}
\hline RX & 40,167 & 11.6 B & $2,882.0$ & 1 & PD & $-55,340$ & -15.9 B & $2,875.9$ \\
OD & 36,446 & 10.5 B & $2,884.5$ & 2 & LG & $-25,243$ & -7.3 B & $2,884.6$
\end{tabular}

$\begin{array}{lllllllll}\text { AK } & 30,600 & 8.8 \text { B } & 2,887.7 & 3 & \text { CC } & -12,824 & -3.7 \text { B } & 2,890.7\end{array}$

$\begin{array}{lllllllll}\text { KZ } & 21,757 & 6.3 \text { B } & 2,879.0 & 4 & C S & -11,359 & -3.3 \text { B } & 2,891,7\end{array}$

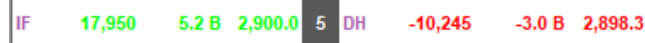

$\begin{array}{llllllllll}\text { ZP } & 9,073 & 2.6 \text { B } & 2,883.3 & 6 & \text { YU } & -9,924 & -2.9 \text { B } & 2,885.9\end{array}$

$\begin{array}{llllllllll}\text { KS } & 4,252 & 1.2 \text { B } & 2,878.9 & 7 & \text { DR } & -9,430 & -2.7 \text { B } & 2,890.1\end{array}$

$\begin{array}{llllllllll}\text { AO } & 1,989 & 570.8 \mathrm{M} & 2,870.0 & 8 & \text { CG } & -6,541 & -1.9 \text { B } & 2,887.9\end{array}$

$\begin{array}{lllllllllll}\text { KK } & 1,542 & 444.2 \mathrm{M} & 2,881.6 & 9 & \mathrm{XA} & -4,750 & -1.4 \mathrm{~B} & \mathbf{2 , 8 8 0 . 0}\end{array}$

$\begin{array}{llllllllll}\text { Al } & 1,029 & 297.2 \mathrm{M} & 2,888.9 & 10 & \text { YP } & -4,103 & -1.2 \mathrm{~B} & 2,887.7\end{array}$

$\begin{array}{llllllllll}\mathrm{KI} & 40 & 11.5 \mathrm{M} & 2,880.0 & 11 & \mathrm{GR} & \mathbf{- 3 , 1 0 9} & \mathbf{- 8 9 6 . 2} \mathrm{M} & \mathbf{2 , 8 8 1 . 3}\end{array}$

$\begin{array}{lll}-1,795 & -519.4 \text { M } \quad 2,889.9\end{array}$

$\begin{array}{llllllllll}\text { YB } & 10 & 2.9 \mathrm{M} & 2,892.0 & 13 & \mathrm{CP} & -1,640 & -470.8 \mathrm{M} & 2,873.7\end{array}$

AZ $\quad 0 \quad 2,890.014 \mathrm{HP}=-1,531-438.0 \mathrm{M} \quad 2,868.4$

$2,868.4$

$\begin{array}{lll}-1,492 & -432.5 \mathrm{M} \quad 2,895.9\end{array}$

$\begin{array}{lll}-1,000 & -290.0 \mathrm{M} \quad 2,900.0\end{array}$

$\begin{array}{lll}-950 & -273.3 \mathrm{M} \quad 2,876.8\end{array}$

$\begin{array}{lll}-622 & -179.1 M \quad 2,878.8\end{array}$

$-461 \quad-133.1 \mathrm{M} \quad 2,886.2$

TVal 58.6 B | FNVal 24.6 B | TLot 203,248 | Avg 2884.9

Gambar 5 jumlah pembelian investor asing

Sumber : Indopremier Securities

Gambar 5 mencatat bahwa investor asing masih melakukan pembelian yaitu sebanyak 24,6 Milyar Rupiah. Hal ini berarti saham BBTN masih layak untuk dipegang (hold). Pengawasan terhadap aliran dana asing dilakukan setiap kali sinyal deadcross indikator stochastic muncul. Untuk memperkuat keputusan, rasio fibonacci pada tanggal 22 Agustus 2017 menghasilkan sinyal breakout. Dengan memperhatikan aliran dana investor asing, investor tidak perlu cemas jika rasio fibonacci akan melakukan kesalahan karena sekarang aliran dana investor asing yang menjadi indikator utama.

Dengan melakukan pola yang sama, saham BBTN masih layak untuk dipegang (hold) sampai pada tanggal 18 September 2017 sekalipun banyak sinyal deadcross yang dilalui karena dana investor asing masih terus masuk ke saham BBTN. Setelah hampir sebulan lamanya indikator stochastic menghasilkan sinyal deadcross namun tetap disertai arus masuk dana asing, mulai tanggal 19 September 2017 indikator stochastic kembali menghasilkan sinyal deadcross dan terjadi arus dana keluar investor asing. Berikut data transaksi investor yang ditampilkan pada Gambar 6. 


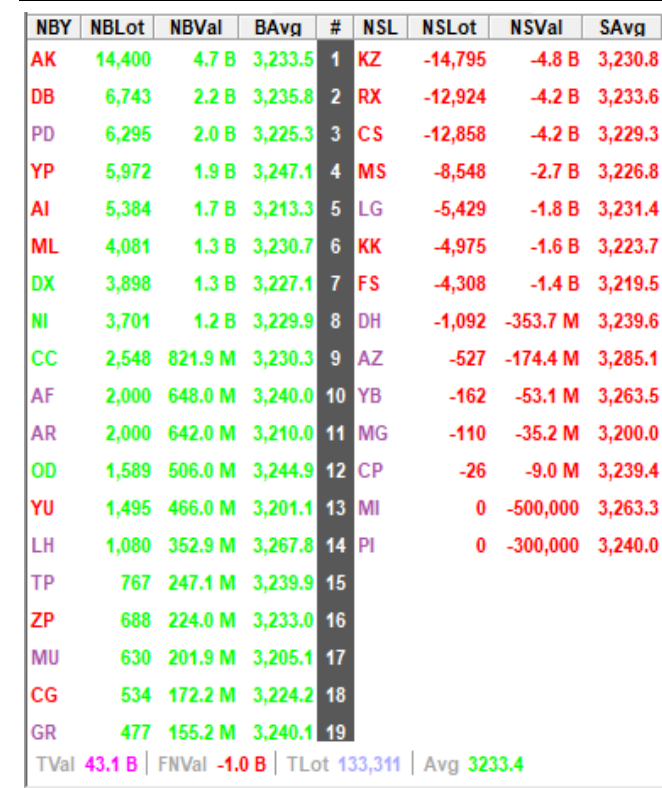

Gambar 6 dana keluar investor asing Sumber : Indopremier Securities

Keluarnya aliran dana asing sebesar 1 Milyar Rupiah menjadi sinyal jual bagi investor dikisaran harga $\mathrm{Rp}$ 3.230. Apabila investor melakukan transaksi seperti langkah diatas maka sejak tanggal 31 Juli 2017 sampai pada tanggal 19 September 2017 imbal hasil yang diperoleh sebesar 25,19\%. Jika seandainya investor tidak melakukan penjualan maka sampai pada tanggal 30 Oktober 2017 keuntungan (capital gain) yang diperoleh hanya sekitar 6,9\% karena saham BBTN terus menurun sampai pada harga $\mathrm{Rp}$ 2.760 .

\section{KESIMPULAN}

Berdasarkan penelitian yang dilakukan dapat ditarik beberapa kesimpulan sebagai berikut :

1. Terjadinya false signal dalam indikator stochastic dan fibonacci pada saham ASII, BBTN dan TLKM disebabkan oleh adanya aktivitas arus dana investor asing. Arus dana investor asing memicu terjadinya fluktuasi harga yang tidak dapat dibaca oleh kedua indikator tersebut. Arus masuk dana investor asing menyebabkan kenaikan harga saham dan arus keluar dana asing menyebabkan penurunan harga saham.

2. Solusi untuk mengantisipasi terjadinya false signal yaitu mengkombinasikan sinyal analisis teknikal yang dihasilkan oleh indikator stochastic dan rasio fibonacci dengan arah arus dana investor asing.

3. Strategi yang dibutuhkan untuk mengikuti arus dana investor asing dalam mengelola portofolio saham dilakukan secara pasif dan aktif. Strategi pasif berarti menunggu konfirmasi arus dana investor asing, sedangkan strategi aktif adalah melakukan pembelian atau penjualan dalam merespon keluar masuknya arus dana investor asing.

\section{DAFTAR PUSTAKA}

Argha.(2012).Teori Bandarmologi AccumulationDistribution.Dikutip dari www.creativetrader.com/bandarmology-theoryaccumulation-distribution-3/

Badan Pengembangan dan Pembinaan Bahasa.(2008).Kamus Besar Bahasa Indonesia edisi 3.Jakarta: Balai Pustaka

Dermawan.(2017).Cara Mengambil Keuntungan dari tren Pergerakan Harga Saham.Dikutip dari www.finansialku.com/tren-sikluspasar-saham-part-1 /amp/ 2 April 2018, 11.00 WIB

Dermawan.(2017).Kenali Dasar Analisis Teknikal Sebagai Alat Bantu Trading.Dikutip dari www.finansialku.com/dasar-analisisteknikal-trading/amp/ 2 April 2018, 11.10 WIB

Filbert, Ryan.(2014).Bandarmology:Membeli Saham Gaya Bandar Bursa.Jakarta:Elex Media Komputindo

Filbert, Ryan.(2014).Investasi Saham ala Swing Trader Dunia.Jakarta:Elex Media Komputindo

Frensidy, Budi.(2009).Analisis Pengaruh Aksi Jual-Beli Asing,Kurs, dan Indeks Hang Seng Terhadap Indeks Harga Saham Gabungan di Bursa Efek Jakarta dengan Model Garch. Program Ekstensi Akuntansi FE UI

Graham, Benjamin.(2016).The Intelligent Investor: The Definitive Book on Value Investing Edisi Revisi.New York: HarperCollins

Hartanto,William.(2017).The Tao of Bandarmology.Jakarta.Elex Media Komputindo

Kompas.(2018).http://ekonomi.kompas.com/read/ 2017/12/27/080000626/catatan-2017-saatindonesia-akhirnya-menyandang-statusinvestment-grade- 7 Maret 2018, 10.22 WIB

Luciana, Reis.,Roberto Meurer.,dan Sergio Da Silva.(2008).Stock Returns and Foreign Investment in Brazil.Munich: Federal University of Santa Catarina

May,Ellen.(2011).Smart Traders Not Gamblers.Jakarta: Gramedia Pustaka Utama 
Muthmainah, Dinda.(2017).OJK Ramal IHSG Tembus Level 7.000 Tahun Depan. Dikutip http://m.cnnindonesia.com/ekonomi/20171 230012715-92-265655-/ojk-ramal-ihsgtembus-level-7000-tahun-depan 24 April 2018, 13.05 WIB

Putri, Nisa.(2017).Ramalan Bahana Sekuritas IHSG Tembus 7.000 di 2018. Dikutip dari www.kontan.co.id/news/ramalan-bahanasekuritas-ihsg-tembus-7000-di-2018 24 April 2018, 13.15 WIB

Sfteam.(2013).Indikator Leading dan Lagging.Dikutip dari www.seputarforex.com 3 April 2018, 11.00 WIB

Singgih,Benny dan Anna.(2015).Gini Caranya Dapat Untung dari Bisnis Saham dan Reksadana. Yogyakarta: Certe Posse

Soumare, Issouf dan Fulbert.(2011).Causality between FDI and Financial Market Development:Evidence from Emerging Markets.Munich: Laval University,Canada

Sugiyono.(2011).Metode Penelitian kuantitatif kualitatif dan R\&D.Bandung:Alfabeta

Sukmadinata, Nana Syaodih.(2011).Metode Penelitian Pendidikan.Bandung: PT Remaja Rosdakarya
Sulistyono, Ari.(2011).Jebakan False Signal. Dikutip dari www.manajementrading.blogspot.co.id/201 1/04/jebakan-false-signal.html?m=1 5 April 2018, 10.40 WIB

Tandelilin, Eduardus.(2010).Portofolio dan Investasi Teori dan Aplikasi.Yogyakarta: Kanisius

Tim Indonesian Stock Exchange.(2014).Sekolah Pasar Modal Level 2.Jakarta: Bursa Efek Indonesia

Utomo, Satrio.(2011).Foreign Fund Flow. Dikutip dari www.rencanatrading.com 5 April 2018, 12.00 WIB

Vibby,Santo.(2016).Trading Strategy:Fundamental Analysis.Jakarta: Santo Vibby Traders Academy. Dikutip dari http://svta.co.id/trading-strategy-

fundamental-analysis/ 7 April 2018, 11.15 WIB

Wira,Desmond.(2010).Analisis Teknikal untuk Profit Maksimal.Jakarta: PT Exceed

Wira,Desmond.(2011).Analisis Fundamental Saham.Jakarta: Escaeva 